TITLE:

\title{
Pyrolysis reactions of Japanese cedar and Japanese beech woods in a closed ampoule reactor
}

$\operatorname{AUTHOR}(S)$ :

Asmadi, Mohd; Kawamoto, Haruo; Saka, Shiro

CITATION:

Asmadi, Mohd ... [et al]. Pyrolysis reactions of Japanese cedar and Japanese beech woods in a closed ampoule reactor. Journal of Wood Science 2010, 56(4): 319-330

\section{ISSUE DATE:}

2010-08

URL:

http://hdl.handle.net/2433/126722

\section{RIGHT:}

The original publication is available at www.springerlink.com; この論文 は出版社版でありません。引用の際には出版社版をご確認ご利用くだ さい。; This is not the published version. Please cite only the published version. 


\section{Original paper}

Title: Pyrolysis reactions of Japanese cedar and Japanese beech woods in a closed ampoule reactor

Authors and affiliation:

Mohd Asmadi, Haruo Kawamoto*, Shiro Saka

Full postal address of the person to whom proofs are to be sent:

Graduate School of Energy Science, Kyoto University

Yoshida-honmachi, Sakyo-ku, Kyoto 606-8501, Japan

* Corresponding author: Tel/Fax: +81-75-753-4737

Email address: kawamoto@energy.kyoto-u.ac.jp (H.Kawamoto)

Key words Pyrolysis $\cdot$ secondary reaction $\cdot$ hardwood $\cdot \operatorname{softwood} \cdot \operatorname{tar}$ composition $\cdot$ char reactivity

Part of this article was presented at the $59^{\text {th }}$ Annual Meeting of the Japan Wood Research Society, Matsumoto, Japan, March 2009. 
Abstract Chemical structures of hemicellulose and lignin are different for two distinct types of wood species, i.e. softwood and hardwood. Such differences are expected to affect the pyrolysis behaviors. In this paper, they were discussed for Japanese cedar wood (a softwood) and Japanese beech wood (a hardwood) pyrolyzed in a closed ampoule reactor $\left(\mathrm{N}_{2} / 600^{\circ} \mathrm{C} /\right.$ 40-600 s). The oven-dried samples were used for the purpose of eliminating the influence of initial water. Their demineralized samples (prepared by acid washing) were also used to understand the influence of the minerals contained in the wood samples. As a result, some features were disclosed for secondary char (coke) formation, char reactivity, tar formation and subsequent decomposition and so on. 


\section{Introduction}

Devolatilization products of wood and other lignocellulosic biomass are known to be degraded further as the pyrolytic reactions proceed. These phenomena have been discussed with "primary pyrolysis" and "secondary reactions", although their strict definitions are difficult. In this paper, devolatilization step to form the volatilie products such as levoglucosan (1,6-anhydro- $\beta$-D-glucopyranose), glycolaldehyde, hydroxyacetone and furans (from wood polysaccharides) and substituted guaiacols and syringols (from lignin) is defined as "primary pyrolysis".

Primary pyrolysis and secondary reactions are the fundamental steps in various thermochemical conversion processes which include wood carbonization, gasification and fast pyrolysis. In wood gasification, primary pyrolysis products, i.e. tar and char, undergo extensive secondary reactions usually in the presence of gasifying agents (oxidants such as steam and oxygen). ${ }^{1}$ On the other hand, such secondary reactions are minimized in fast pyrolysis processes to maximize the oil yield. ${ }^{2}$ Thus, better understanding of the primary pyrolysis and secondary reactions of wood and other lignocellulosic biomass will be helpful in developing more efficient thermochemical processes for effective utilization of biomass as renewable fuels and chemicals.

There are two distinct types of wood species, i.e. softwood and hardwood. Chemical structures of hemicellulose and lignin are known to be different for these groups. Hardwoods contain $O$-acetyl-4-O-methylglucuronoxylan as their main hemicellulose component, while the major hemicellulose of softwoods is galactglucomannan. ${ }^{3}$ Xylan (arabino-4-Omethylglucuronoxylan) is a minor hemicellulose component in softwoods. Content of acetyl group in hardwood hemicellulose is usually higher than that of softwood hemicellulose. ${ }^{3}$ As for lignin, aromatic structure of softwood lignins is mainly guaiacyl-type, whereas hardwood lignins include syringyl-type along with the guaiacyl-nuclei. ${ }^{4}$ Such difference in the aromatic ring structure is also known to result in different compositions of the linkage types of 
phenylpropane-units. ${ }^{5}$ Contents of the condensed structures such as biphenyl type are usually lower in hardwood lignins. Due to such differences in chemical structures of the composing polymers, softwoods and hardwoods are expected to be pyrolyzed differently.

Primary pyrolysis reactivities of wood samples have been studied with their mass-loss behaviors. ${ }^{6-14}$ However, there are few papers ${ }^{6-8}$ which focus on the differences between softwoods and hardwoods. Grønli et al. ${ }^{6}$ compared the thermogravimetric (TG) curves of 5 softwoods and 4 hardwoods in heating up conditions at $5^{\circ} \mathrm{C} / \mathrm{min}$, and they reported that the DTG peaks of devolatilization of hemicellulose in hardwoods were observed at lower temperatures than those of softwoods. From these observations, they concluded that hemicellulose in softwood has lower reactivity in pyrolysis. Similar results have been reported for large wood chips ${ }^{7}$ and cylinders ${ }^{8}$ by the Di Blasi's group.

Primary pyrolysis pathways have been studied by analyzing the pyrolysis products with gas chromatography/ mass spectrometry (GC/MS), ${ }^{11-17}$ nuclear magnetic resonance (NMR) ${ }^{14,18}$ and so on. Various model compounds were used to study the reaction pathways and mechanisms, especially for lignin. ${ }^{19-24}$ As for the secondary reactions of the primary pyrolysis products, many papers deal with the char gasification reactivity ${ }^{25,26}$ in relation to the wood gasification.

Flow-type dual zone reactor systems ${ }^{27-32}$ are used to study the secondary reactions of primary pyrolysis vapor. Antal ${ }^{32}$ reported that the cellulose-derived volatiles were converted into the non-condensable gases more effectively than the lignin-derived volatiles at $500-700^{\circ} \mathrm{C}$ in the presence of steam. Evans and Milne ${ }^{28}$ analyzed the vapor-phase secondary reaction products with molecular-beam mass spectrometry (MBMS). They reported that the primary tars were converted into polyaromatic hydrocarbons (PAHs) via light hydrocarbons, aromatics and oxygenates. Rath and Staudinger ${ }^{33}$ used TG with a consecutive tubular reactor to study the reactivities of the primary vapors which were produced in different temperature ranges. 
Some low MW compounds have been used as the model substances of the primary tars to understand the secondary reaction pathways. ${ }^{34-38}$

Hosoya et al. ${ }^{34-36,39}$ used a closed ampoule reactor to study the secondary reactions of cellulose- and lignin-derived primary pyrolysis products. Their vapor-phase interactions, ${ }^{40}$ secondary char (coke) formation mechanism from the lignin-derived low MW aromatic components ${ }^{36}$ and different decomposition pathways of levoglucosan in vapor- and liquidphases ${ }^{35}$ are studied effectively with this reactor. With the closed ampoule reactor, it is easy to set the heating time of the primary pyrolysis products and to recover whole gaseous, tar and char fractions.

In spite of these studies conducted to understand the primary pyrolysis and secondary reactions, there are no papers dealing with these behaviors systematically compared for softwoods and hardwoods. In this paper, primary pyrolysis and secondary reaction behaviors are compared for Japanese cedar (Cryptomeria japonica) wood (a softwood) and Japanese beech (Fagus crenata) wood (a hardwood) with a closed ampoule reactor under the heat treatment conditions of $\mathrm{N}_{2} / 600^{\circ} \mathrm{C} / 40-600 \mathrm{~s}$.

\section{Experimental}

Materials

Extractive-free wood flour ( $<80$ mesh) prepared from the sapwood of Japanese beech or Japanese cedar was used just after oven-drying at $105^{\circ} \mathrm{C}$ for $24 \mathrm{~h}$. Their demineralized samples were also prepared by the following procedure. Wood flour $(1 \mathrm{~g})$ was stirred in 0.05 $\mathrm{M} \mathrm{HCl} / \mathrm{methanol}(30 \mathrm{ml})$ at room temperature for $24 \mathrm{~h}$. After filtration, the treated wood flour was washed with distilled water repeatedly until the $\mathrm{pH}$ of the supernatant became neutral. This procedure was repeated twice and the demineralized sample was dried at $105^{\circ} \mathrm{C}$ for $24 \mathrm{~h}$. 
In this procedure, the wood constituent polymers are expected not to be removed from the wood samples, because methanol and water are not good solvent for these polymers. Compositions of the major inorganic elements in the wood samples are listed in Table 1, which were determined with inductively coupled plasma mass spectrometry (ICP-MS) on a Agilent ICP-MS 7500CS after incination in air at $600^{\circ} \mathrm{C}$ for $2 \mathrm{~h}$. Detectable amounts of residues were not observed after incination of the demineralized samples $\left(100 \mathrm{mg}\right.$, air/ $600^{\circ} \mathrm{C} /$ $2 \mathrm{~h})$. As for the chemical compositions of beech and cedar woods, it is generally known that the former has a larger and a smaller amounts of xylan and lignin, respectively, as described in the relevant report: ${ }^{41} 21.3-26.2 \%$ (beech), 9.6-12.0\% (cedar); lignin: 18.3-24.2\% (beech), $28.0-34.8 \%$ (cedar).

Heat treatment in a closed ampoule reactor

Heat treatment method and the apparatus are described in the previous paper. ${ }^{39}$ Wood sample $(10 \mathrm{mg})$ was placed at the bottom of a Pyrex glass ampoule (internal diameter: $8.0 \mathrm{~mm}$, length: $120 \mathrm{~mm}$, and glass thickness: $1.0 \mathrm{~mm}$ ). After exchanging the air inside the reactor with $\mathrm{N}_{2}$, the ampoule was closed and heated in a muffle furnace preheated at $600^{\circ} \mathrm{C}$ for 40 600 s. During the treatment, the ampoule was maintained in the upright setting. After the treatment, the ampoule was immediately cooled by flowing air for $1 \mathrm{~min}$, and noncondensable gases were analyzed by GC as described later. After the gas analysis, the ampoule was extracted with methanol $(1.0 \mathrm{ml} \times 2)$ to obtain methanol-soluble (tar) and insoluble (char) fractions. Char was observed at the bottom of reactor and on upper side of the reactor wall, which are defined as primary char and secondary char (or coke), respectively, in this paper. Char yield was determined from the weight difference of the glassware after incination of char in air at $600^{\circ} \mathrm{C}$ for $2 \mathrm{~h}$. Water formed in heat treatment was determined by analyzing the methanol-soluble fractions with a Karl Fisher moisture titrator MKC-520 
(Kyoto Electronics MFG). Tar yield was obtained by subtracting the total weight of gas, char and water from that of wood sample.

Gas analysis

Gas sampling method is described in detail elsewhere. ${ }^{39}$ Non-condensable gases were determined with GC by using a Shimadzu GC-18B under the following conditions; column: Shincarbon ST (4.0 $\mathrm{m} \times 3.0 \mathrm{~mm}$ in diameter); carrier gas: argon; flow rate: $20 \mathrm{ml} / \mathrm{min}$; column temperature: $40^{\circ} \mathrm{C}(0-1 \mathrm{~min}), 40-200^{\circ} \mathrm{C}\left(1-21 \mathrm{~min}, 8^{\circ} \mathrm{C} / \mathrm{min}\right), 200^{\circ} \mathrm{C}(21-31 \mathrm{~min})$; detector: thermal conductivity detector (TCD); retention times: $\mathrm{H}_{2}(3.8 \mathrm{~min}), \mathrm{N}_{2}$ (9.6 min), $\mathrm{CO}$ (11.2 min), $\mathrm{CH}_{4}(16.8 \mathrm{~min})$ and $\mathrm{CO}_{2}(22.6 \mathrm{~min})$.

Tar analysis

The methanol-soluble fractions were analyzed by GC-MS for determination of mainly ligninderived low MW products. From the total-ion chromatograms, the yields of low MW products were determined by comparing their peak areas with that of $p$-dibromobenzene as an internal standard. The analysis was carried out by using a Hitachi G-7000 gas chromatograph and a Hitachi M9000 mass spectrometer under the following conditions: column, Shimadzu CBP-M25-O25 (length: $25 \mathrm{~m}$, diameter: $0.25 \mathrm{~mm}$ ); injector temperature: $250^{\circ} \mathrm{C}$, column temperature: $40^{\circ} \mathrm{C}(1 \mathrm{~min}), 40 \rightarrow 300^{\circ} \mathrm{C}(1 \rightarrow 53 \mathrm{~min}), 300^{\circ} \mathrm{C}(53 \rightarrow 60 \mathrm{~min})$; carrier gas; helium; flow rate; $1.5 \mathrm{ml} / \mathrm{min}$; emission current; $20 \mu \mathrm{A}$; ionization time; $2.0 \mathrm{~ms}$. Identification of the products was conducted by comparing their mass fragmentation patterns and retention times with those of authentic compounds or literature data. ${ }^{16,42}$

The carbohydrate-derived tar components were mainly determined with the ${ }^{1} \mathrm{H}-\mathrm{NMR}$ analysis of the $N, N$-dimethylformamide (DMSO)- $d_{6}$-soluble fractions, which were prepared 
by extracting the heat treated products with DMSO- $d_{6}(1.0 \mathrm{ml})$ instead of methanol. ${ }^{1} \mathrm{H}-\mathrm{NMR}$ spectra were recorded with a Bruker AC-400 (400 MHz) spectrometer in the presence of 10 $\mu \mathrm{L}$ of $\mathrm{D}_{2} \mathrm{O}$ and $p$-dibromobenzene as an internal standard, and chemical shifts are shown in $\delta$ values by using trimethylsilane as an internal standard. Yields of acetic acid, hydroxyacetone, methanol, levoglucosan, formic acid, furfural, 5-hydroxymethylfurfural (5-HMF) were determined with the peak areas or peak heights of the signals at $\delta 1.9\left(\mathrm{CH}_{3}\right), \delta 2.0\left(\mathrm{CH}_{3}\right), \delta 3.2$ $\left(\mathrm{CH}_{3}\right), \delta 5.1\left(\mathrm{C}_{1}-\mathrm{H}\right), \delta 8.3$ (aldehyde-H), $\delta 9.6$ (aldehyde-H), and $\delta 9.7$ (aldehyde-H), respectively, as compared with those of $p$-dibromobenzene. The yields of glycolaldehyde and acetaldehyde were determined as the oxime derivatives ( $E$ - and $Z$-isomers) by the addition of $2.0 \mathrm{mg}$ of hydroxylamine hydrochloride in the DMSO- $d_{6}$ solution [oximes of glycolaldehyde $(-\underline{\mathrm{HC}}=\mathrm{N}-\mathrm{OH}): \delta 7.3$ for $E$-isomer, $\delta 6.7$ for $Z$-isomer; oximes of acetaldehyde $\left(\mathrm{CH}_{3}-\mathrm{CH}=\mathrm{N}\right.$ $\mathrm{OH}): \delta 1.71$ for $E$-isomer, $\delta 1.69$ for $Z$-isomer].

All experiments were repeated several times, and yields of the products were not so different in these sets of experiment.

\section{Results and discussion}

Gas, tar, char and water formation behaviors

Pictures of the reactors after tar-extraction and methanol-soluble tar fractions are illustrated in Fig. 1. Figure 2 shows the time-course changes of the gas, tar, char and water yields. Influence of demineralization on these yields is understandable more easily with the yield ratio (summarized in Fig. 3), which is defined as yield (demineralized wood)/ yield (original wood). From the definition, the yield ratio $>1.0$ indicates higher yield in demineralized wood. 
As discussed later in tar composition, reaction mode changed from primary pyrolysis to secondary reactions in the period of 40-120 s.

Secondary char (coke) was observed on the upper-side of the reactor wall, and this formation proceeded up to the higher part in longer heating time of $600 \mathrm{~s}$ (Fig. 1). The secondary char formation was more significant in beech than cedar, especially in their demineralized samples. Demineralization enhanced the secondary char formation, and this tendency was more striking in beech. This type of secondary char is reported to be characteristic of lignin. ${ }^{14}$ Thus, these differences would be related to the different chemical structures of lignins.

Color of the methanol-soluble tar fractions changed darker in $40-80 \mathrm{~s}$, and then became pale yellow or almost colorless in an increase in the heating time. Conjugated colored substances may decompose in 80-600 s. Minerals in wood tend to reduce the color, and this tendency was more striking in beech.

As for the product yields (Figs. 2 and 3), a major difference between two original wood samples was observed in char yield. The char yield from the beech wood was reduced significantly from $22 \mathrm{wt} \%$ (40 s) to only $3 \mathrm{wt} \%(600 \mathrm{~s})$, and the gas yield increased significantly in the period of $120 \mathrm{~s}(41 \mathrm{wt} \%)-600 \mathrm{~s}(57 \mathrm{wt} \%)$. On the other hand, the gas, tar, char and water yields were not so different for 120 and $600 \mathrm{~s}$ in the cedar wood.

Interestingly, such high char reactivity of beech wood was observed only in the ovendried samples and not in the air-dried one; char yield (air-dried): $27 \mathrm{wt} \%$ (120 s), $25 \mathrm{wt} \%$ (600 s). Water contained in the beech wood may change the primary char formation reaction and this may result in lowering the char reactivity, although the role of water is not known presently. Reactivity of beech wood char was also reduced in the demineralized sample. Thus, minerals in the beech wood are suggested to be responsible for this high char reactivity. Even in the demineralized samples, the beech wood char still had higher reactivity than cedar. 
Unlike the beech wood, demineralization rather increased the reactivity of cedar wood char slightly.

As for the tar cracking reaction to form non-condensable gases (Figs. 2 and 3), reduction rates of the tar yields in the period of 40-600 s increased after demineralization. The water yields showed similar tendency. With these trends, the non-condensable gas yields dramatically increased in the cedar wood. Since the char yields from the demineralized cedar wood were not so different for 120 and $600 \mathrm{~s}$, these higher gas yields arise from the enhanced tar cracking reactivity. Water (vapor) would be used in this tar cracking. In case of the beech wood, the gas yields (120 and $600 \mathrm{~s}$ ) were not so different for original and demineralized samples, because the enhanced gas formation through tar cracking is compensated with the reduced char reactivity.

Unlike the above results, the gas yield rather decreased after demineralization in $40 \mathrm{~s}$ for both species. This would be related to the influence of minerals on the primary pyrolysis step. Enhanced char formation in the presence of minerals is known in wood pyrolysis.

Change in the tar composition

The polysaccharide- and lignin-derived tar components were mainly analyzed by ${ }^{1} \mathrm{H}-\mathrm{NMR}$ and GC/MS analysis of the tar fractions, respectively. Since all of the authentic compounds were not available in GC/MS analysis, the yields of lignin-derived products are shown only in the ratio of peak areas against the area of $p$-dibromobenzene as an internal standard.

\section{${ }^{1} H-N M R$ analysis}

An example of the ${ }^{1} \mathrm{H}-\mathrm{NMR}$ spectra of the DMSO- $d_{6}$-soluble tar fractions is shown in Fig. 4. Although the spectrum is a little bit complicated, the well-resolved signals assigned for 
anhydrosugar [levoglucosan (4)], furans [furfural (8) and 5-hydroxymethyl furfural (6, 5HMF)], ketone [hydroxyacetone (2)], aldehydes [glycolaldehyde (7) and acetaldehyde (9)], acids [acetic acid (1) and formic acid (5)] and alcohol [methanol (3)] were observed as their deuterioxy derivatives. Glycolaldehyde forms dimers and oligomers in solution, and this makes the quantification difficult. ${ }^{43}$ Acetaldehyde was also suggested to be involved in such dimerization and oligomerization, because the yields determined by the analysis of the DMSO- $d_{6}$-solutions were much lower than those with the corresponding oximes. And hence, these compounds were quantified as their oximes in the ${ }^{1} \mathrm{H}-\mathrm{NMR}$ spectra which were measured after the addition of oximation reagent into the DMSO- $\boldsymbol{d}_{6}$-solutions. ${ }^{35,39,40,43}$

Figure 5 shows the time-course changes of the identified tar components. Most of these compounds are derived from cellulose and hemicellulose, although acetic acid, formic acid and methanol can be formed also from lignin. ${ }^{40}$ The compositions of the polysaccharidederived tar components drastically changed depending on the heating time. These compounds disappeared within 120 or $200 \mathrm{~s}$ except for acetic acid and methanol, which were still observed even in $600 \mathrm{~s}$. Thus, acetic acid and methanol are the important low MW components in the tar fractions after long heating time. Hosoya et al. ${ }^{39}$ reported that most of the cellulose-derived tar components were decomposed to form the non-condensable gases within $120 \mathrm{~s}$ under the similar heating conditions, while the lignin-derived tar was comparatively stable for gas formation. Based on these lines of information, most of the polysaccharide-derived tar components would be converted into the non-condensable gases effectively.

Levoglucosan, glycolaldehyde, 5-HMF and formic acid had the highest yields in $40 \mathrm{~s}$ and disappeared within 120 or $200 \mathrm{~s}$. These observations indicate that these compounds are formed in the early stage of pyrolysis. On the other hand, formation of acetaldehyde, acetic acid (cedar) and methanol from the original wood samples tend to be delayed (maximum yields in 80 or $120 \mathrm{~s}$ ). Formation of hydroxyacetone, furfural and acetic acid (beech) were 
also delayed by demineralization. Minerals in wood samples may catalyze these formation probably by acting as base catalysts.

Demineralization tends to increase the product (Fig. 5) yields in $40 \mathrm{~s}$ except for hydroxyacetone and acetic acid. As a result, total yield of compounds 1-9 in $40 \mathrm{~s}$ from the cedar wood increased by demineralization from $8.7 \mathrm{wt} \%$ (35.5 wt $\%$ ) (original) to $14.0 \mathrm{wt} \%$ (48.0 wt\%) (demineralized) (yield in parenthesis: based on tar fraction). Such increasing yields of the polysaccharide-derived tars in $40 \mathrm{~s}$ (primary pyrolysis stage) would lead to the higher gas yields observed for the demineralized cedar wood in longer heating time (120 and 600 s, Figs. 2 and 3). As for beech wood, total yields of compounds 1-9 in $40 \mathrm{~s}$ were not so different [14.5 wt\% (45.4 wt\%) (original) and $14.9 \mathrm{wt} \%$ (48.1 wt\%) (demineralized), yield in parenthesis: based on tar fraction]. Large decrease in the acetic acid yield from $4.6 \mathrm{wt} \%$ to $2.1 \mathrm{wt} \%$ is a reason.

Acetic acid is a major product from hardwood pyrolysis. ${ }^{44}$ Formation of about $10 \%$ of acetic acid was reported in pyrolysis of $O$-acetyl-4-O-methylglucuronoxylan at $500^{\circ} \mathrm{C}$ and the yield was reduced down to $1.5 \%$ in the deacetylated xylan. ${ }^{15}$ Accordingly, higher yield of acetic acid from the original beech wood arises from the higher content of the acetyl group in beech hemicellulose (xylan). Alkali and alkaline earth metal cations are considered to be bound to uronic acid units in hemicellulose. ${ }^{45}$ Pan and Richards ${ }^{10}$ clearly demonstrated that demineralization reduced the acetic acid yield from cottonwood (Populus trichocarpa) wood (a hardwood) at $250^{\circ} \mathrm{C}$, while that the yield was recovered up to the level of the original wood by addition of $\mathrm{K}$ cation (content: $0.2 \%$ ) through cation-exchange method. Based on this information, significant reduction in the acetic acid yield by demineralization of the beech wood is explained by elimination of the catalytic effect of metal cations. Alkali metal carboxylates in xylan are expected to act as base catalysts in hydrolysis of the acetyl groups. In the demineralized beech wood, these acetyl groups would be decomposed differently. 
Reduced yield of hydroxyacetone by demineralization would be explained by the two competitive pyrolysis pathways to give levoglucosan and hydroxyacetone, respectively, which have been proposed in cellulose pyrolysis. ${ }^{46,47}$ Minerals may act as base catalysts in retroaldol-type reaction in formation of hydroxyacetone.

\section{GC/MS analysis}

Figure 6 illustrates the total-ion chromatograms in GC/MS analysis of the methanol-soluble tar fractions. Most of these signals were assigned to the lignin-derived low MW products which are categorized into guaiacols, syringols, phenols, cresols, catechols, pyrogallols and PAHs depending on the aromatic structure. Chemical structures of the identified products are summarized in Fig. 7. Anhydrosugars (4 and 33) and C5 carbonyls 10, 12 and 13 are the exceptions, which are mainly formed from cellulose and hemicellulose. Table 2 shows the mass fragments used for identification of the products, especially the syringyl-types and PAHs. Identification of the guaiacyl-types was made according to the previous paper. ${ }^{14}$

Like the polysaccharide-derived products, chemical compositions of the lignin-derived products varied significantly in short heating time of 40-120 s. This trend can be seen in the time-course change of the product yield as illustrated in Figs. 8 (beech) and 9 (cedar). The chromatograms were very different for these species only in relatively short heating time $<80$ s. The cedar wood afforded guaiacols and catechols in $40 \mathrm{~s}$, while the beech wood gave syringols and 3-methoxycatechol along with these cedar-derived products. Contrary to this, their compositions became similar after longer heating time $>80 \mathrm{~s}$. Accordingly, influence of different chemical structures of lignins on the GC/MS-detectable products is large only in primary pyrolysis and early stage of secondary reactions. Demineralization did not change the compound types. 
The aromatic ring structures changed in the direction of guaiacols and syringols $\rightarrow$ catechols, pyrogallols, cresols and phenols $\rightarrow$ PAHs. In the second group, cresols and phenol were comparatively stable and observed even in $600 \mathrm{~s}$. Formation of naphthalenes, phenanthrene and anthracene, which were identified as PAHs, proceeded in longer heating time of $120-600 \mathrm{~s}$.

Transformation mechanism of guaiacols to catechols or $o$-cresols is well-documented. 40,48 Catechols and $o$-cresols are formed through two competitive reactions, i.e. an $\mathrm{O}-\mathrm{CH}_{3}$ bond homolysis pathway ${ }^{40}$ and a radical-induced rearrangement pathway starting from the guaiacyl phenoxy radicals, ${ }^{48}$ respectively. Hosoya et al. ${ }^{36}$ also suggested that the latter reaction is a key step for the secondary char formation. They proposed $o$-quinonemethide as a key intermediate for this char formation.

Along with the change in the aromatic structure, the side-chain structures also changed significantly in 40-80 s. As reported for Japanese cedar milled wood lignin, ${ }^{34}$ unsaturated side-chains $(>\mathrm{C}=\mathrm{C}<, \mathrm{CH}=\mathrm{O}$ and $>\mathrm{C}=\mathrm{O}$ ) were observed in $40 \mathrm{~s}$ which are usually attached to the guaiacol- or syringol-types of aromatic rings. Other types of the aromatic rings observed in the longer heating time of 80-600 s have only saturated groups, i.e. methyl and ethyl groups, or do not have any side-chains. According to the model compound studies, ${ }^{19,24}$ lignin primary pyrolysis forms low MW products with conjugated $>\mathrm{C}=\mathrm{C}<$ and $>\mathrm{C}=\mathrm{O}$ structures. Coniferyl alcohol and stilbene are formed in significant yields from $\beta$-ether- and $\beta$-aryl-types of dimers, respectively. ${ }^{19}$ Nakamura et al. ${ }^{20}$ and Hosoya et al. ${ }^{34}$ also reported that the conjugated $>\mathrm{C}=\mathrm{C}<$ structures are subject to condensation to form higher MW products. Hosoya et al. ${ }^{34}$ indicated that the saturated side-chains are formed through cracking of the side-chains in the condensates.

Based on these tar analysis results, compositional change of the aliphatic and aromatic tar components with an increase in the heating time was clarified as depicted in Fig. 10. 
Change in the gas composition

Figure 11 summarizes the gas compositions (mol\%) and gas yields (wt $\%)$. The yield ratios are also summarized in Fig. 12. For both species, gas composition changed significantly in 40-120 s and was not so different in 120 and $600 \mathrm{~s}$. In $40 \mathrm{~s}$, the proportion of $\mathrm{CO}_{2}$ tends to be larger than those of other gases.

Demineralization increased the methane yields in $40 \mathrm{~s}$ with reduction of the other gas yields. Methane is reported to be formed from lignin methoxyl groups in early stage of pyrolysis. ${ }^{40}$ Methane is formed via the $\mathrm{O}-\mathrm{CH}_{3}$ homolysis to form $\cdot \mathrm{CH}_{3}$ radical and subsequent abstraction of hydrogen. This process is known to be influenced by the polysaccharide-derived tar. Hosoya et al. ${ }^{40}$ clearly demonstrated that the methane yield increased by the action of the polysaccharide-derived tars as $\mathrm{H}$-donors to $\cdot \mathrm{CH}_{3}$ radical. This also leads to the increasing gas yield, especially $\mathrm{CO}$, from the polysaccharide-derived tars. In the present study, yields of $\mathrm{CO}$ and $\mathrm{CO}_{2}$ rather decreased by demineralization. Some complex interactions of lignin with other wood composing polymers and minerals may be involved in these behaviors.

Although the yields are not large, the methane yields from the beech wood samples in $40 \mathrm{~s}$ were greater than those from cedar. These results are consistent with the higher methoxyl content of the beech wood lignin which contains syringyl-units with two methoxyl groups.

In ${ }^{1} \mathrm{H}-\mathrm{NMR}$ analysis of the tar fractions, the signals around 3.7-3.8 ppm (Fig. 4), which were assigned to the lignin methoxyl methyl protons, disappeared in $80 \mathrm{~s}$ (the chromatograms: not shown). Thus, formation of methane in longer heating time $>120 \mathrm{~s}$ originates from other pathway than the $\mathrm{O}-\mathrm{CH}_{3}$ homolysis route.

As already discussed, demineralization increased the yields of polysaccharide-derived tar components in primary pyrolysis stage. This leads to the enhanced gas formation in the secondary reaction stage (120-600 s). As for the gas composition from the cedar wood in 120 
and $600 \mathrm{~s}$, the proportion of $\mathrm{CO}_{2}$ tends to be smaller in the demineralized samples(Fig. 12). This would be related to the increasing contribution of the cracking reactions of the polysaccharide-derived tars. Such influence was not clearly observed for beech wood, since the gas yields and compositions are also changed by reducing the char reactivity.

Based on these results, it was found that minerals in wood samples affect the gas formation behaviors in primary pyrolysis and secondary reaction stages differently. The minerals increase the $\mathrm{H}_{2}, \mathrm{CO}$ and $\mathrm{CO}_{2}$ yields and reduce the methane yield in primary pyrolysis stage. In secondary reaction stage, the minerals lower the gas yield through reducing the formation of polysaccharide-derived tars with comparatively high gas formation reactivities .

\section{Conclusions}

The following results were obtained by comparing the pyrolysis behaviors of Japanese cedar wood (a softwood) and Japanese beech wood (a hardwood) in a closed ampoule reactor (ovendried/ $\left.\mathrm{N}_{2} / 600^{\circ} \mathrm{C} / 40-600 \mathrm{~s}\right)$.

1. Secondary char (coke) formation was more significant in beech than cedar. Minerals in wood reduced the secondary char formation.

2. Beech wood char had higher reactivity than cedar wood char. Demineralization of beech wood reduced this high char reactivity.

3. Minerals in wood sample reduced the yields of polysaccharide-derived tars with relatively high gas formation reactivities in primary pyrolysis stage. This reduces the gas formation in secondary reaction stage.

4. Yield of acetic acid was larger in beech than in cedar. Minerals in wood samples catalyzed acetic acid formation. 
5. The aromatic tar compositions, which are mainly derived from lignin, were quite different only in the primary pyrolysis stage and early stage of the secondary reactions. In longer heating time, the compositions became similar.

6. Minerals in wood sample affected the gas formation in primary pyrolysis and secondary reaction stages differently. The minerals increased the gas yield in the former stage with reducing the methane yield, while lowered the gas yield in the latter stage. Beech wood tends to produce more methane than cedar wood in primary pyrolysis stage. 


\section{Acknowledgement}

This work was supported by a Grant-in-Aid for Scientific Research (B)(2) (No.

203801035007, 2008.4-2011.3) and Kyoto University Global COE program of "Energy Science in the Age of Global Warming". 


\section{References}

1. Bridgwater AV (1995) The technical and economic feasibility of biomass gasification for power generation. Fuel 74(5):631-653.

2. Bridgwater AV, Peacocke GVC (2000) Fast pyrolysis process for biomass. Renewable and Sustainable Energy Reviews 4: 1-73.

3. Timell TE (1965) Wood hemicelluloses: part II. Adv Carbohydr Chem 19:409-483.

4. Nakano J, Higuchi T, Sumimoto T, Ishizu A (1983) Mokuzai kagakuk (in Japanese). Uni Publishing, Tokyo, pp 145-227.

5. Adler E (1977) Lignin chemistry -past, present and future. Wood Sci Technol 11(3): 169218.

6. Grønli MG, Várhegyi G, Di Blasi C (2002) Thermogravimetric analysis and devolatilization kinetics of wood. Ind Eng Chem Res 41:4201-4208.

7. Di Blasi C, Branca C, Santoro A, Bermudez RAP (2001) Weight loss dynamics of wood chips under fast radiative heating. J Anal Appl Pyrol 57:77-90.

8. Di Blasi C, Branca C, Santoro A, Hernandez EG (2001) Pyrolytic behavior and products of some wood varieties. Combust Flame 124:165-177.

9. Müller-Hagedorn M, Bockorn H, Krebs L, Müller U (2003) A comparative kinetic study on the pyrolysis of three different wood species. J Anal Appl Pyrol 68-69:231-249.

10. Pan WP, Richards GN (1989) Influence of metal ions on volatile products of pyrolysis of wood. J Anal Appl Pyrol 16: 117-126.

11. Branca C, Giudicianni P, Di Blasi C (2003) GC/MS Characterization of liquids generated from low-temperature pyrolysis of wood. Ind Eng Chem Res 42: 3190-3202.

12. Sipilä K, Kuoppala E, Fagernäs L, Oasmaa A (1998) Characterization of biomass-based flash pyrolysis oils. Biomass Bioenergy 14(2): 103-113. 
13. Alén R, Kuoppala E, Oesch P (1996) Formation of the main degradation compound groups from wood and its components during pyrolysis. J Anal Appl Pyrol 36: 137-148.

14. Hosoya T, Kawamoto H, Saka S, (2007) Pyrolysis behaviors of wood and its constituent polymers at gasification temperature. J Anal Appl Pyrol 78:328-336.

15. Šimkovic I, Varhegyi G, Antal MJ (1988) Thermogravimetric/mass spectrometric characterization of the thermal decomposition of (4-O-Methyl-D-Glucorono)-D-Xylan. $\mathrm{J}$ Appl Polym Sci 36:721-728.

16. Ralph J and Hatfield RD (1991) Pyrolysis-GC-MS characterization of forage materials. J Agri Food Chem 39:1426-1437.

17. Pouwels AD, Tom A, Eijkel GB, Boon JJ (1987) Characterisation of beech wood and its holocellulose and xylan fractions by pyrolysis-gas chromatography-mass spectrometry. $\mathbf{J}$ Anal Appl Pyrol 11:417-436.

18. Pindoria RV, Lim J-Y, Hawkes JE, Lazaro M-J, Herod AA, Kandiyoti R (1997) Structural characterization of biomass pyrolysis tars/ oils from eucalyptus wood waste: effect of $\mathrm{H}_{2}$ pressure and sample configuration. Fuel 76(11): 1013-1023.

19. Kawamoto H, Horigoshi S, Saka S (2007) Pyrolysis reactions of various lignin model dimers. J Wood Sci 53: 168-174.

20. Nakamura T, Kawamoto H, Saka S (2007) Condensation reactions of some lignin related compounds at relatively low pyrolysis temperature. J Wood Chem Technol 27: 121-133.

21. Kawamoto H, Nakamura T, Saka S (2008) Pyrolytic cleavage mechanisms of lignin-ether linkages: a study on $p$-substituted dimers and trimers. Holzforsch 62: 50-56.

22. Kawamoto H, Ryoritani M, Saka S (2008) Different pyrolytic cleavage mechanisms of $\beta$ ether bond depending on the side-chain structure of lignin dimers. J Anal Appl Pyrol 81: 88-94.

23. Nakamura T, Kawamoto H, Saka S (2008) Pyrolysis behavior of Japanese cedar wood lignin studied with various model dimers. J Anal Appl Pyrol 81: 173-182. 
24. Watanabe T, Kawamoto H, Saka S (2009) Radical chain reactions in pyrolytic cleavage of the ether linkages of lignin model dimers and a trimer. Holzforsch 63(4): 424-430.

25. Di Blasi C (2009) Combustion and gasification rates of lignocellulosic chars. Prog Energ Combust 35:121-140.

26. DeGroot WF, Shafizadeh F (1984) Kinetics of gasification of douglas fir and cottonwood chars by carbon dioxide. Fuel 63:210-216.

27. Boroson ML, Howard JB, Longwell JP, Peters WA (1989) Product yields and kinetics from the vapor phase cracking of wood pyrolysis tars. AIChE J 35(1):120-128.

28. Evans RJ, Milne TA (1987) Molecular characterization of the pyrolysis of biomass. 1. Fundamentals. Energy Fuel 1(2):123-137.

29. Boroson ML, Howard JB, Longwell JP, Peters WA (1989) Heterogenous cracking of wood pyrolysis over fresh wood char surfaces. Energy Fuel 3:735-740.

30. Franco C, Pinto F, Gulyurtlu I, Cabrita I (2003) The study of reactions influencing the biomass steam gasification process. Fuel 82:835-842.

31. Morf P, Hasler P, Nussbaumer T (2002) Mechanisms and kinetics of homogenous secondary reactions of tar from continuous pyrolysis of wood chips. Fuel 81:843-853.

32. Antal Jr MJ (1983) Effects of reactors severity on the gas-phase pyrolysis of cellulosederived and kraft lignin-derived volatile matter. Ind Eng Chem Prod Res Dev 22: 366-375.

33. Rath J, Staudinger G (2001) Cracking reactions of tar from pyrolysis of spruce wood. Fuel 80:1379-1389.

34. Hosoya T, Kawamoto H, Saka S (2008) Secondary reactions of lignin-derived primary tar components. J Anal Appl Pyrol 83:78-87.

35. Hosoya T, Kawamoto H, Saka S (2008) Different pyrolytic pathways of levoglucosan in vapor- and liquid/solid-phases. J Anal Appl Pyrol 83:64-70.

36. Hosoya T, Kawamoto H, Saka S (2009) Role of methoxyl group in char formation from lignin-related compounds. J Anal Appl Pyrol 84: 79-83. 
37. Friderichsen AV, Shin EJ, Evans RJ, Nimlos MR, Dayton DC, Ellison GB (2001) The pyrolysis of anisole $\left(\mathrm{C}_{6} \mathrm{H}_{5} \mathrm{OCH}_{3}\right)$ using a hyperthermal nozzle. Fuel 80:1747-1755.

38. Shin EJ, Hajaligol MR, Rasouli F (2004) Heterogenous cracking of catechol under partially oxidative conditions. Fuel 83:1445-1453.

39. Hosoya T, Kawamoto H, Saka S (2008) Pyrolysis gasification reactivities of primary tar and char fractions from cellulose and lignin as studied with a closed ampoule reactor. $\mathbf{J}$ Anal Appl Pyrol 83:71-77.

40. Hosoya T, Kawamoto H, Saka S (2009) Solid/liquid- and vapor-phase interactions between cellulose- and lignin-derived pyrolysis products. J Anal Appl Pyrol 85: 237-246.

41. Migita N, Yonezawa Y, Kondo T (1968) Wood Chemistry (In Japanese), Kyoritsu Shuppan, pp72.

42. Lima CF, Barbosa LCA, Marcelo CR, Silvério FO and Colodette JL (2008) Comparison between analytical pyrolysis and nitrobenzene oxidation for determination of syringyl/guaiacyl ratio in eucalptus spp. lignin. Bioresources 3(3):701-712.

43. Hosoya T, Kawamoto H, Saka S (2006) Oximation-trimethylsilylation method for analysis of wood pyrolysate. J Anal Appl Pyrol 77: 121-126.

44. Güllü D and Demirbas A (2001) Biomass to methanol via pyrolysis process. Energy Convers Manage 42:1349-1356.

45. DeGroot WF (1985) Preliminary investigation of the association of inorganic cations with carboxylic acid groups in wood. Carbohydr Res 142: 172-178.

46. Piskorz J, Radlein D. Scott DS (1989) pretreatment of wood and cellulose for production of sugars by fast pyrolysis. J Anal Appl Pyrol 16: 127-142.

47. Richards GN (1987) Glycolaldehyde from pyrolysis of cellulose. J Anap Appl Pyrol $10: 251-255$.

48. Dorrestijn E, Mulder P (1999) The radical-induced decomposition of 2-methoxyphenol. J Chem Soc Perkin Trans 2, 777-780. 


\section{List of tables and figures}

Fig. 1. Pictures of the ampoule reactors and the methanol-soluble tar fractions after heat treatment of the original and demineralized wood samples (oven-dried/ $\mathrm{N}_{2} / 600^{\circ} \mathrm{C} / 40-600 \mathrm{~s}$ ).

Fig. 2. Yields of gas, tar, char, and water in heat treatment of the original and demineralized wood samples (oven-dried/ $\mathrm{N}_{2} / 600^{\circ} \mathrm{C}$ ).

Fig. 3. Yield ratios (demineralized/original) of gas, tar, char and water in heat treatment of the original and demineralized wood samples (oven-dried/ $\mathrm{N}_{2} / 600^{\circ} \mathrm{C} / 40-600 \mathrm{~s}$ ). Gas $(\Delta)$, tar (O), char $(\bullet)$, water $(\square)$ *Yield ratio (demineralized/original): yield (demineralized wood)/yield (original wood).

Fig. 4. ${ }^{1} \mathrm{H}-\mathrm{NMR}$ spectrum of the tar fraction obtained from heat treatment of the original beech wood (oven-dried) in $\mathrm{N}_{2}$ at $600^{\circ} \mathrm{C}$ for $40 \mathrm{~s}$. (Solvent: DMSO- $d_{6}$ including $10 \mu \mathrm{L}$ of

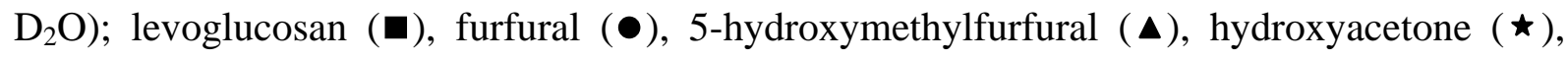
acetaldehyde $(\bullet)$.

Fig. 5. Yields of tar components in heat treatment of the original and demineralized wood samples (oven-dried/ $\mathrm{N}_{2} / 600^{\circ} \mathrm{C} / 40-600 \mathrm{~s}$ ). Original wood (๑); demineralized wood (O).

Fig. 6. Total-ion chromatograms of the methanol-soluble tar fractions obtained from the original wood samples (oven-dried/ $\mathrm{N}_{2} / 600^{\circ} \mathrm{C} / 40-600$ s). a: internal standard (pdibromobenzene). 
Fig. 7. Chemical structures of the compounds identified in GC-MS analysis.

Fig. 8 Time-course changes of tar components in heat treatment of the original beech wood (oven dried/ $\mathrm{N}_{2} / 600^{\circ} \mathrm{C} / 40-600 \mathrm{~s}$ ). ${ }^{*}$ Relative peak height: peak height of compound/ peak height of internal standard ( $p$-dibromobenzene).

Fig. 9. Time-course changes of tar components in heat treatment of the original cedar (oven dried/ $\left.\mathrm{N}_{2} / 600^{\circ} \mathrm{C} / 40-600 \mathrm{~s}\right) .{ }^{*}$ Relative peak height: peak height of compound/ peak height of internal standard ( $p$-dibromobenzene).

Fig. 10. Time-course changes in chemical compositions of tar fractions (oven dried/ $\mathrm{N}_{2} /$ $\left.600^{\circ} \mathrm{C} / 40-600 \mathrm{~s}\right)$.

Fig. 11. Gas compositions in heat treatment of the original and demineralized wood samples

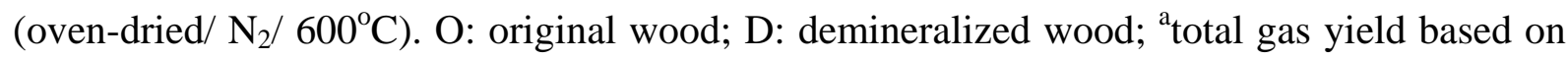
oven dry basis, wt $\%$.

Fig. 12. Yield ratios (demineralized/original) of gaseous products in heat treatment of the original and demineralized wood samples (oven-dried $/ \mathrm{N}_{2} / 600^{\circ} \mathrm{C}$ ). *Yield ratio (demineralized/original): yield (demineralized wood)/yield (original wood).

Table 1 Compositions of major inorganic elements in beech and cedar wood samples

Table 2 Identification of the products by their mass spectra 

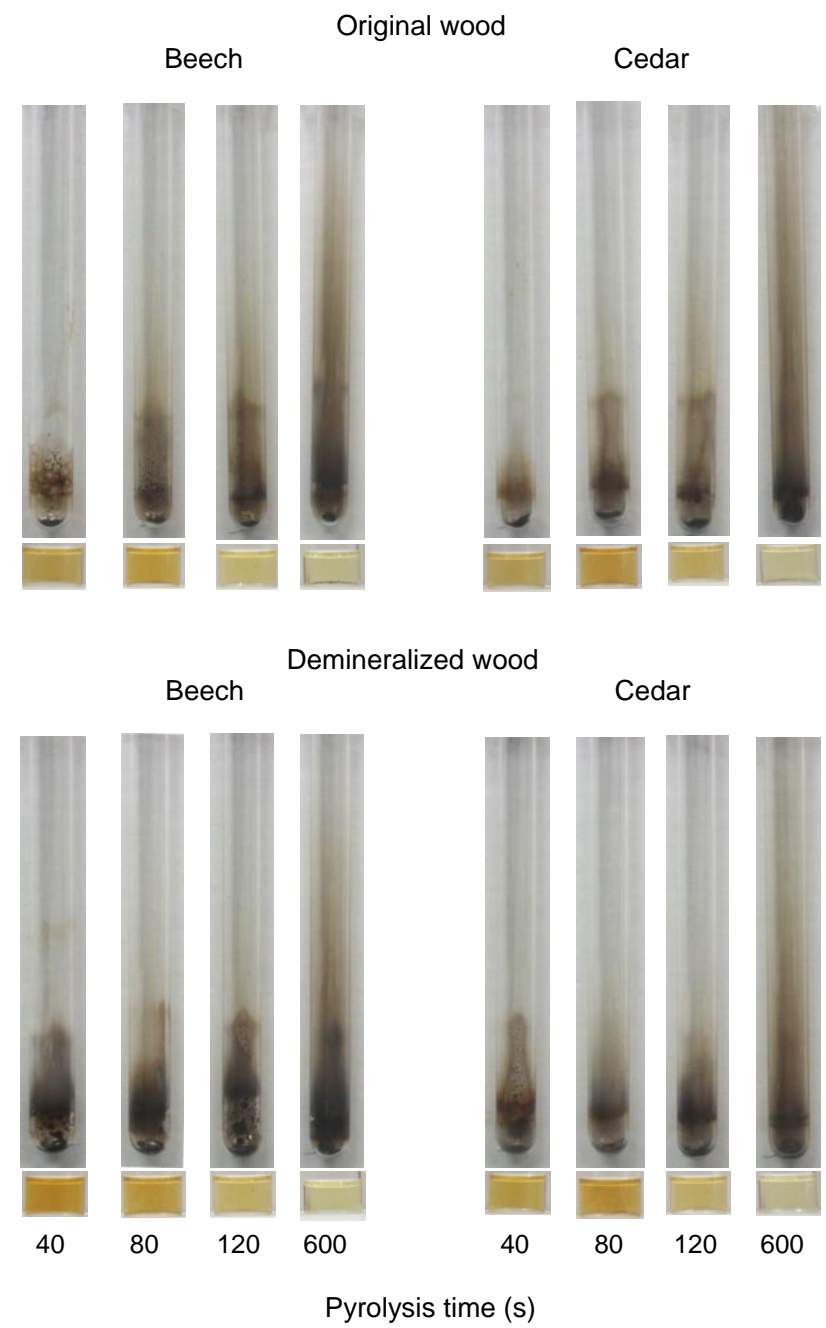

Fig. 1. Pictures of the ampoule reactors and the methanol-soluble tar fractions after heat treatment of the original and demineralized wood samples (oven-dried/ $\mathrm{N}_{2} / 600^{\circ} \mathrm{C} / 40-600 \mathrm{~s}$ ). 


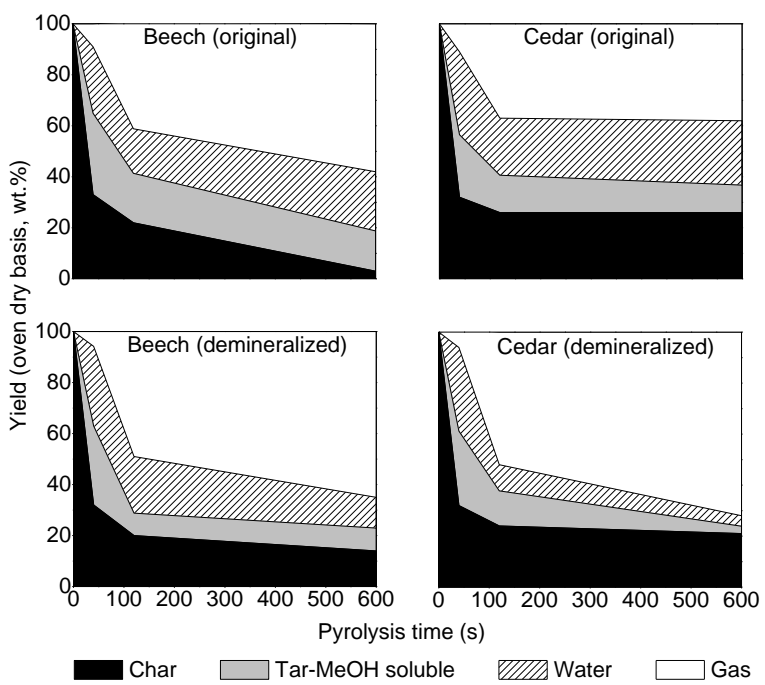

Fig. 2. Yields of gas, tar, char, and water in heat treatment of the original and demineralized wood samples (oven-dried/ $\mathrm{N}_{2} / 600^{\circ} \mathrm{C}$ ). 


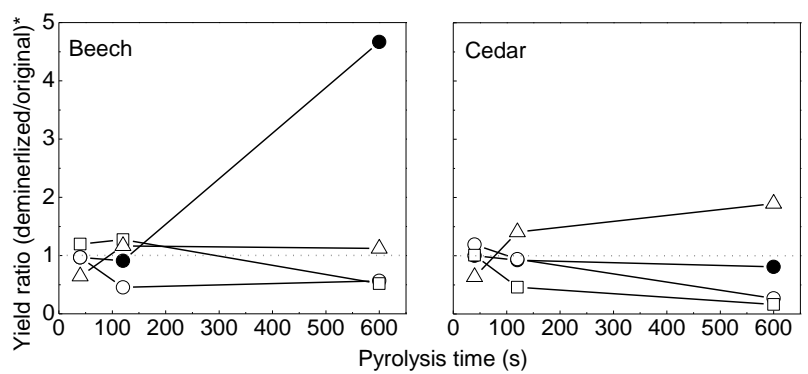

Fig. 3. Yield ratios (demineralized/original) of gas, tar, char and water in heat treatment of the original and demineralized wood samples (oven-dried/ $\mathrm{N}_{2} / 600^{\circ} \mathrm{C} / 40$ 600 s). Gas $(\Delta)$, tar $(O)$, char $(\bullet)$, water $(\square)$. *Yield ratio (demineralized/original): yield (demineralized wood)/yield (original wood). 


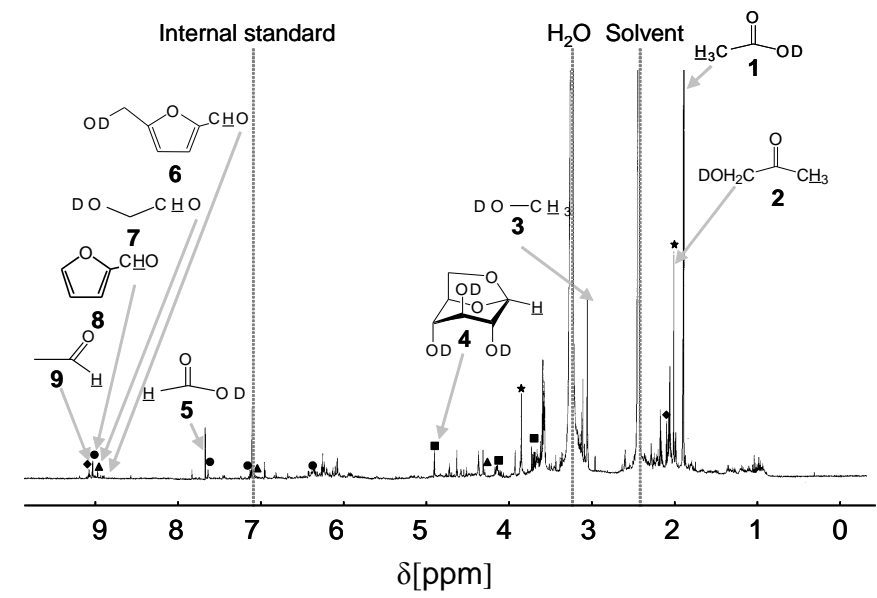

Fig. 4. ${ }^{1} \mathrm{H}-\mathrm{NMR}$ spectrum of the tar fraction obtained from heat treatment of the original beech wood (ovendried) in $\mathrm{N}_{2}$ at $600^{\circ} \mathrm{C}$ for $40 \mathrm{~s}$. (Solvent: DMSO- $d_{6}$

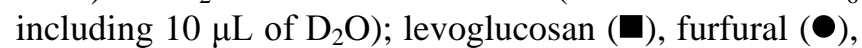
5-hydroxymethylfurfural ( $\mathbf{\Delta})$, hydroxyacetone $(\star)$, acetaldehyde $(\bullet)$. 

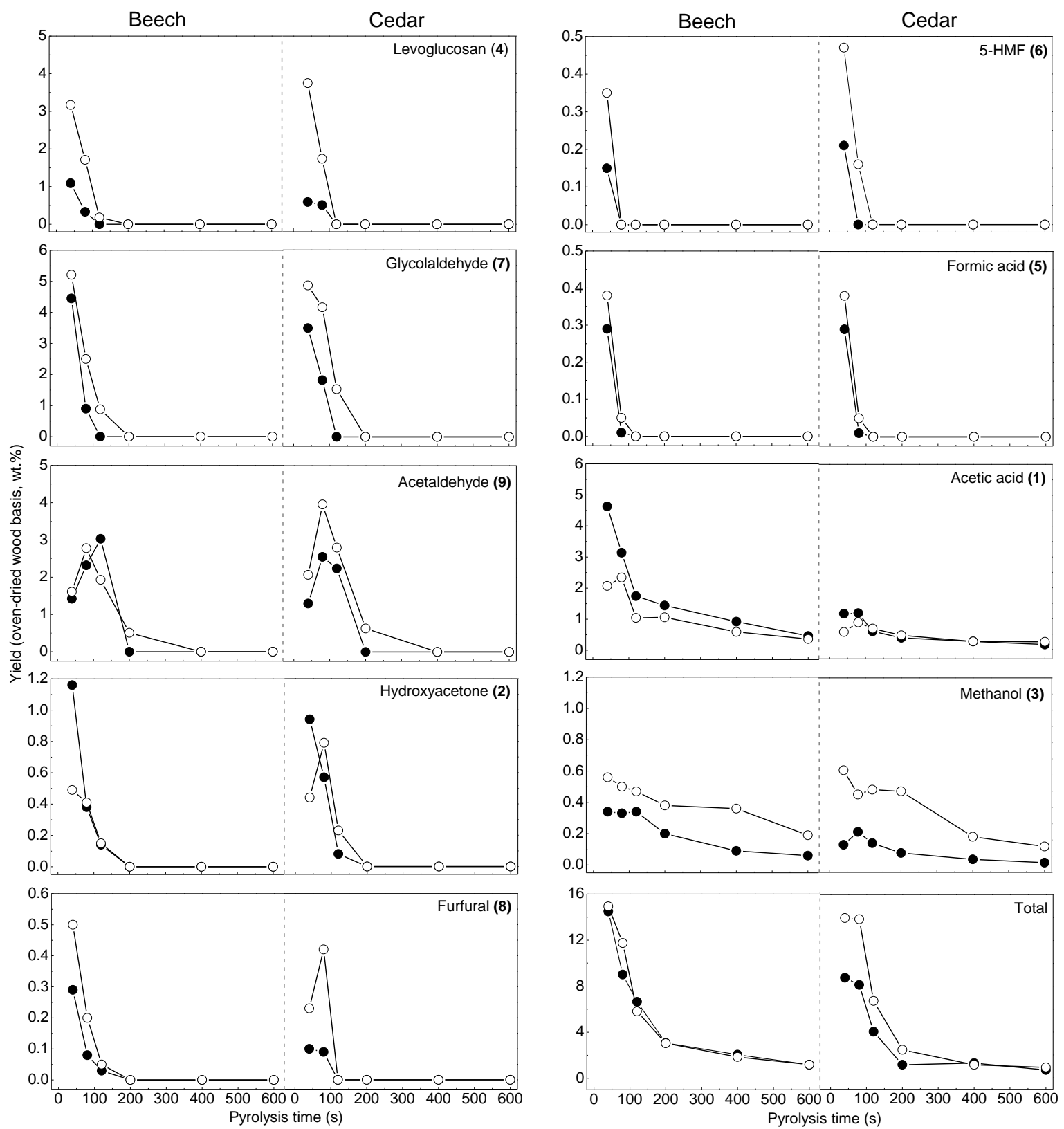

Fig. 5. Yields of tar components in heat treatment of the original and demineralized wood samples (ovendried/ $\left.\mathrm{N}_{2} / 600^{\circ} \mathrm{C} / 40-600 \mathrm{~s}\right)$. Original wood $(\bullet)$; demineralized wood (O). 


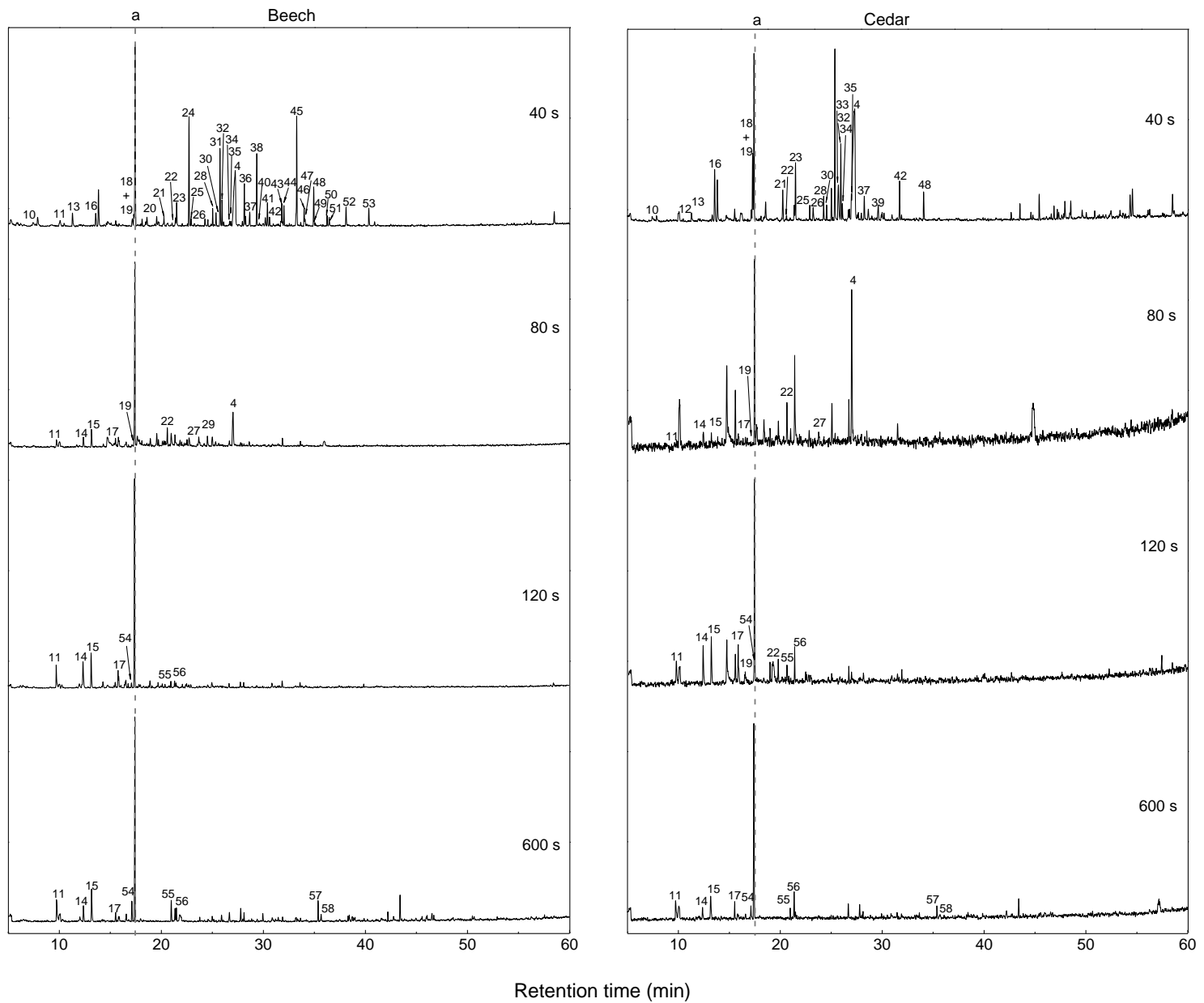

Fig. 6. Total-ion chromatograms of the methanol-soluble tar fractions obtained from the original wood samples (oven-dried/ $\mathrm{N}_{2} / 600^{\circ} \mathrm{C} / 40-600 \mathrm{~s}$ ). a: internal standard (p-dibromobenzene). 


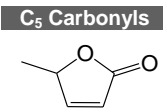

2, 5-Dihydro-5-methylfuran-2-one (10)

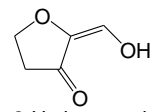

2-Hydroxymethylenetetrahydrofuran-3-one (12)

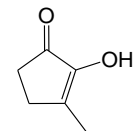

2-Hydroxy-3-methyl2-cyclopenten-1-one

(13)

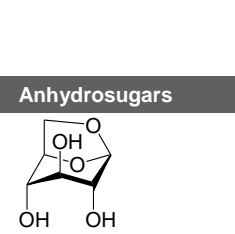

Levoglucosan (4)

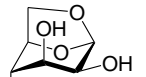

$\mathrm{OH}$

Levomannosan (33)

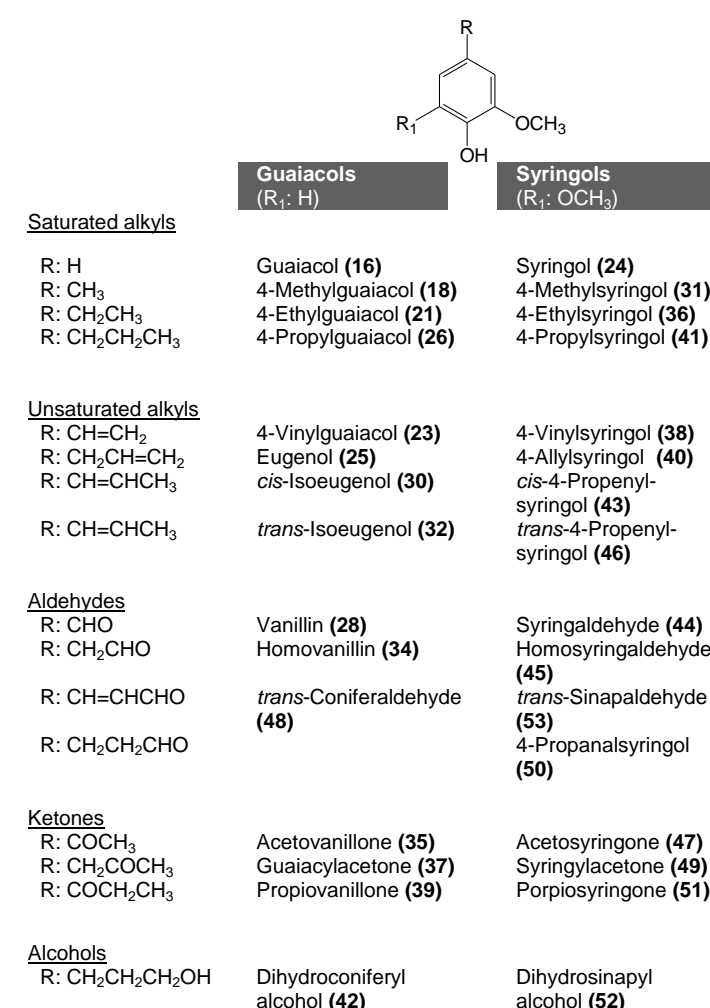

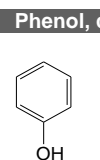

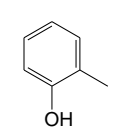

Phenol (11)

o-Cresol (14)<smiles>Oc1ccccc1O</smiles>

$\mathrm{OH}$

2, 4-Xylenol

(17)

Pyrocatechol

(19)
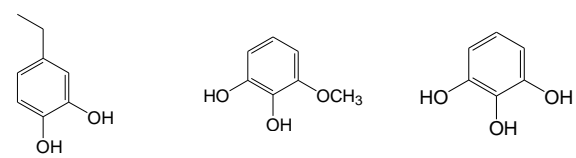

4-Ethyl-

catechol (27)

3-Methoxy-

catechol (20)

Pyrogallol (29)

p-Cresol (15)

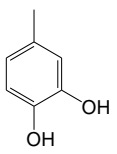

4-Methyl-

catechol (22)

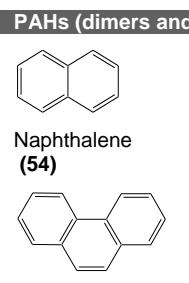

trimers)

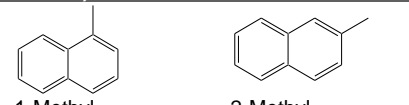

1-Methyl-

2-Methyl-

naphthalene(55) naphthalene (56)

Phenanthrene

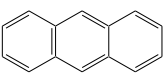

(57)

Anthracene (58)

Fig. 7. Chemical structures of the compounds identified in GC-MS analysis. 

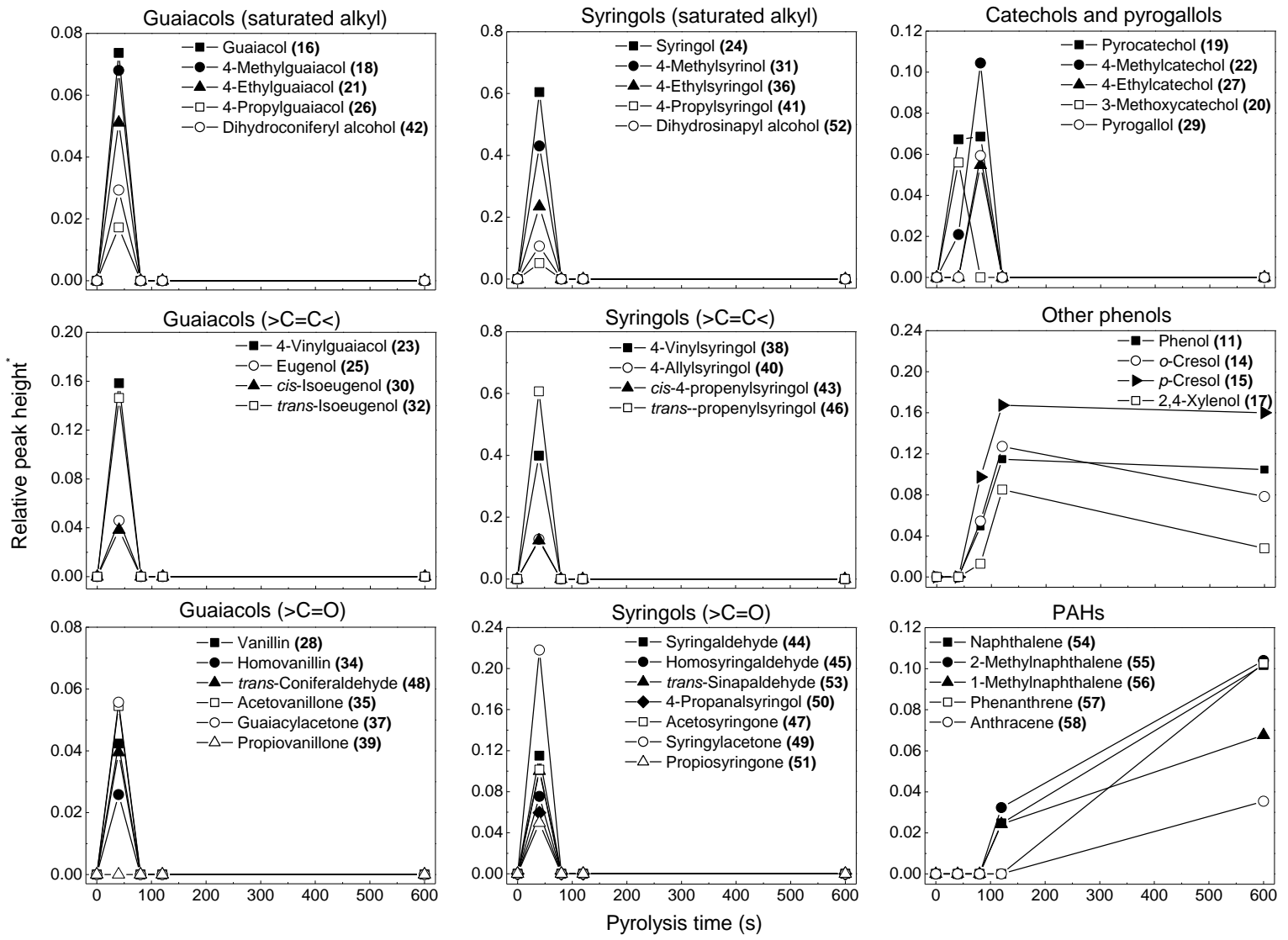

Fig. 8 Time-course changes of tar components in heat treatment of the original beech wood (oven dried/ $\mathrm{N}_{2} /$ $\left.600^{\circ} \mathrm{C} / 40-600 \mathrm{~s}\right) .{ }^{*}$ Relative peak height: peak height of compound/ peak height of internal standard ( $p$ dibromobenzene). 

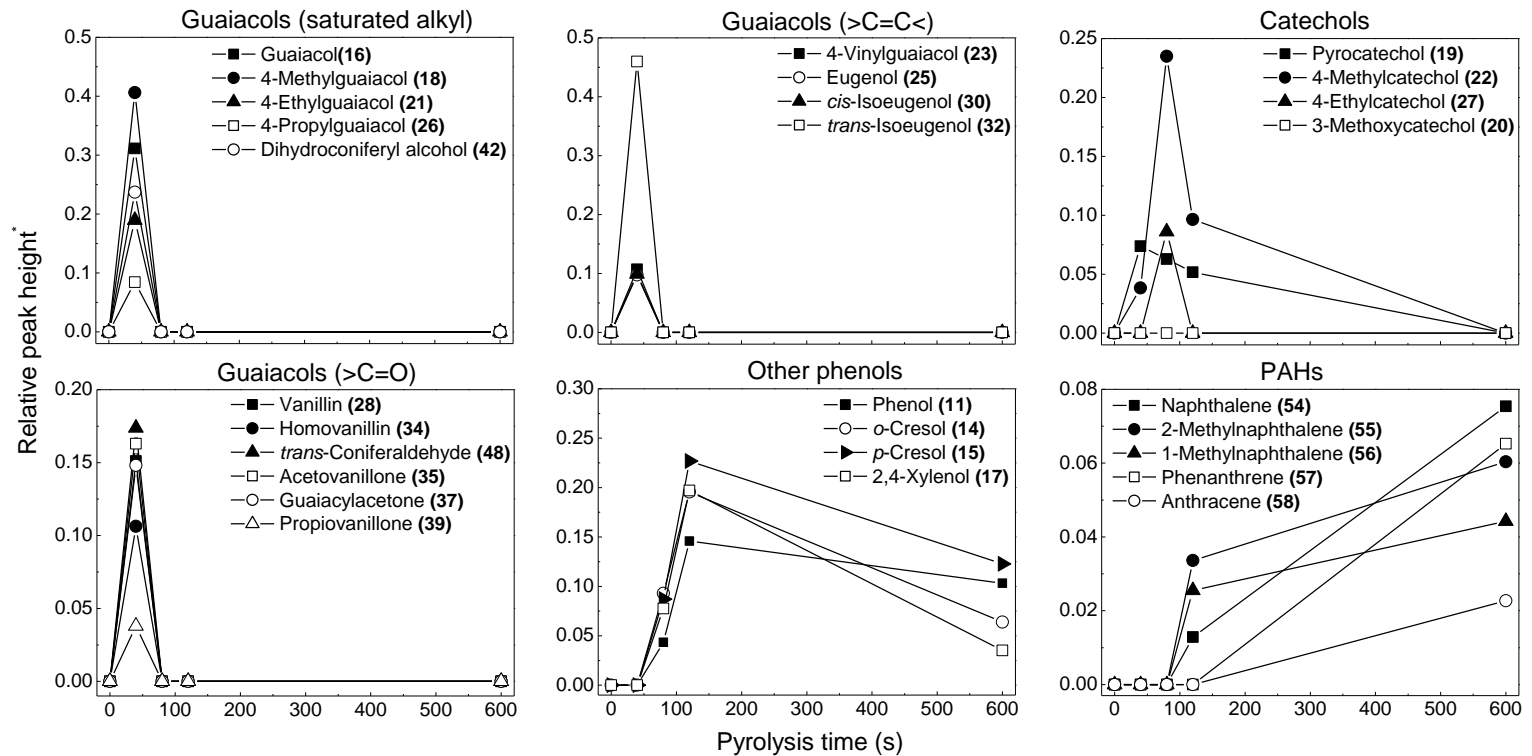

Fig. 9. Time-course changes of tar components in heat treatment of the original cedar (oven dried/ $\mathrm{N}_{2} /$ $600^{\circ} \mathrm{C} / 40-600 \mathrm{~s}$ ). "Relative peak height: peak height of compound/ peak height of internal standard ( $p$ dibromobenzene). 


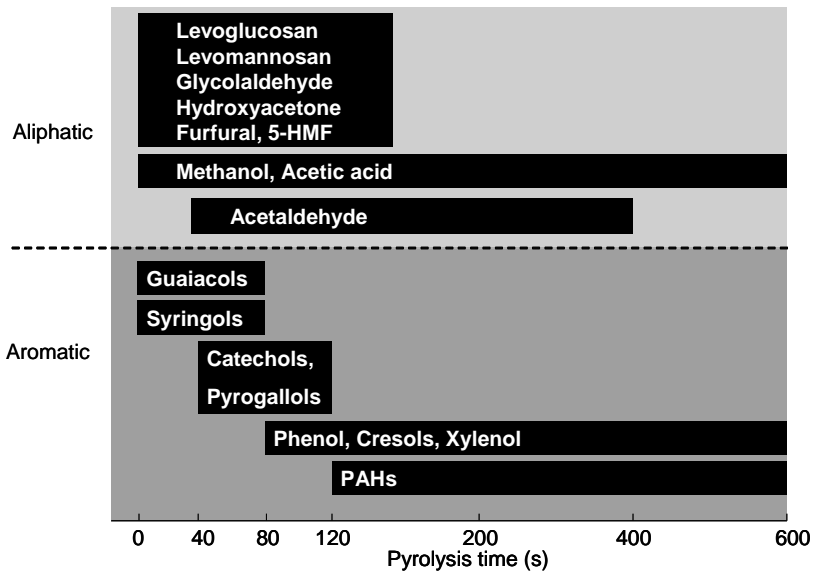

Fig. 10. Time-course changes in chemical compositions of tar fractions (oven dried/ $\mathrm{N}_{2} / 600^{\circ} \mathrm{C} / 40-600 \mathrm{~s}$ ). 


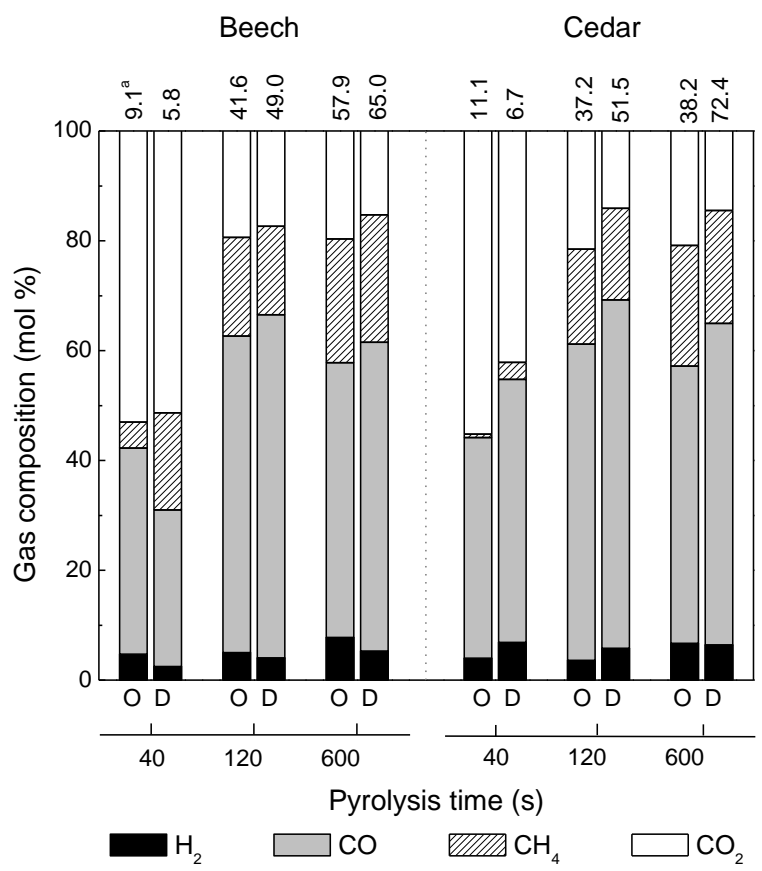

Fig. 11. Gas compositions in heat treatment of the original and demineralized wood samples (oven-dried/ $\mathrm{N}_{2} / 600^{\circ} \mathrm{C}$ ). O: original wood; D: demineralized wood; atotal gas yield based on oven dry basis, wt $\%$. 


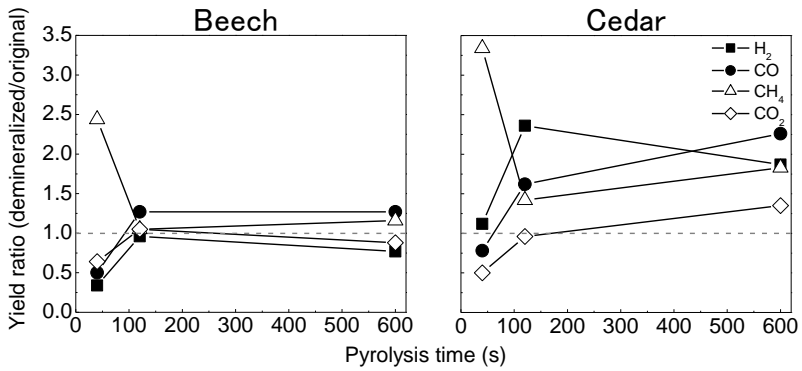

Fig. 12. Yield ratios (demineralized/original) of gaseous products in heat treatment of the original and demineralized wood samples (oven-dried $/ \mathrm{N}_{2} / 600^{\circ} \mathrm{C}$ ). *Yield ratio (demineralized/original): yield (demineralized wood)/yield (original wood). 
Table 1 Compositions of major inorganic elements in beech and cedar wood samples

\begin{tabular}{lllllll}
\hline \multirow{2}{*}{ Wood species } & \multicolumn{5}{c}{ Content of inorganic species (ppm) } \\
\cline { 2 - 7 } & $\mathrm{Ca}$ & $\mathrm{Fe}$ & $\mathrm{Mg}$ & $\mathrm{Na}$ & $\mathrm{K}$ & $\mathrm{Cu}$ \\
\hline Beech & 770 & 17 & 300 & 85 & 830 & 1.04 \\
Cedar & 600 & 5 & 100 & 47 & 400 & 1.35 \\
\hline
\end{tabular}


Table 2 Identification of the products by their mass spectra

\begin{tabular}{|c|c|c|c|}
\hline No. & MW & Major El-fragments & $\begin{array}{l}\text { Identification } \\
\text { method }^{\text {a }}\end{array}$ \\
\hline 20 & 140 & $140,125,97,79,51,39,28$ & $\mathrm{R}$ \\
\hline 24 & 154 & $154,155,139,111,96,93,65$ & $\mathrm{R}$ \\
\hline 29 & 126 & $126,108,80,52,39$ & $\mathrm{R}$ \\
\hline 31 & 168 & $168,169,153,125,107,85,79,77,53$ & $\mathrm{R}$ \\
\hline 36 & 182 & $167,182,168,107,79,28$ & $L^{16}$ \\
\hline 37 & 180 & $137,180,138,122,94,73,43,32,28$ & $R$ \\
\hline 38 & 180 & $\begin{array}{l}180,181,165,137,122,119 \\
91,77,65,51,43,39,32,28\end{array}$ & $L^{16}$ \\
\hline 39 & 180 & $151,180,123116,77,51,43,29$ & $L^{16}$ \\
\hline 40 & 194 & $\begin{array}{l}194,195,179,163,151,131 \\
119,103,91,77,65\end{array}$ & $\mathrm{R}$ \\
\hline 41 & 196 & $167,196,168,123,43,32,28$ & $L^{16}$ \\
\hline 42 & 137 & $137,182,138,122,91,77,40,32,28$ & $L^{16}$ \\
\hline 43 & 194 & $194,195,179,151,131,119,103,91,77,65$ & $L^{16}$ \\
\hline 44 & 182 & $182,183,181,167,153,111,93,65,53,29$ & $\mathrm{R}$ \\
\hline 45 & 196 & $167,196,168,123,122,78,29$ & $L^{16}$ \\
\hline 46 & 194 & $194,195,193,151,131,119,91,77,65$ & $L^{16}$ \\
\hline 47 & 196 & $181,196,153,43,32,28$ & $\mathrm{R}$ \\
\hline 49 & 210 & $167,210,168,123,43,28$ & $L^{16}$ \\
\hline 50 & 210 & $167,210,182,154,122,118,77,53$ & $L^{44}$ \\
\hline 51 & 210 & $181,210,153,65,32,28$ & $L^{16}$ \\
\hline 52 & 168 & $168,212,153,123,108,91,77,43,28$ & $L^{16}$ \\
\hline 53 & 208 & $\begin{array}{l}\mathbf{2 0 8}, 180,177,165,137,122 \\
119,91,77,66,51\end{array}$ & $\mathrm{R}$ \\
\hline 54 & 128 & $128,129,127,102,63,51$ & $\mathrm{R}$ \\
\hline 55 & 142 & $141,143,142,115,89$ & $\mathrm{R}$ \\
\hline 56 & 142 & $142,143,141,139,115,89,63$ & $\mathrm{R}$ \\
\hline 57 & 178 & $178,188,179,150,89,76$ & $\mathrm{R}$ \\
\hline 58 & 178 & $178,189,188,177,76,63$ & $\mathrm{R}$ \\
\hline
\end{tabular}

Bold figure shows base-ion peak

Identified with authentic compound (R) and the mass fragmentation pattern reported in the literature (L). 